\title{
BOUNDARY CROSSING AND LEARNING: A STUDY IN "JOB ROTATION" SITUATIONS
}

\section{TRAVESSIA DE FRONTEIRA E APRENDIZAGEM: UM ESTUDO EM SITUAÇÕES}

DE "JOB ROTATION"

Recebido em 21.07.2018. Aprovado em 24.10.2018

Avaliado pelo sistema double blind review

DOI: http://dx.doi.org/10.12712/rpca.v12i4.12616

\section{Maria Isabel Peixoto Guimarães \\ belguimaraes@prof.iag.puc-rio.br \\ Pontifícia Universidade Católica do Rio de Janeiro (PUC), Rio de Janeiro/RJ, BRASIL \\ ORCID: https://orcid.org/0000-0002-2749-9505}

\section{Jeane Lucena}

lucenajeane@gmail.com

Pontifícia Universidade Católica do Rio de Janeiro (PUC), Rio de Janeiro/RJ, BRASIL

ORCID: https://orcid.org/0000-0003-1464-7924

\section{Sandra Regina da Rocha-Pinto}

sanpin@iag.puc-rio.br

Pontifícia Universidade Católica do Rio de Janeiro (PUC), Rio de Janeiro/RJ, BRASIL

ORCID: https://orcid.org/0000-0002-5121-4231

\begin{abstract}
The purpose of this study was to understand how individuals experience learning in the workplace, and shed light on possible factors that may contribute to an environment conducive to learning in organizations. A phenomenographic approach was chosen with the intention to capture the variation in individuals' learning conceptions. The findings revealed three conceptions of learning: Learning resulting in individual change; learning resulting in collective practice (routine) change; and learning resulting in innovation. Those conceptions were explained by five explanatory dimensions: learning concept; learning drivers; learning content; learning means; learning obstacles; and learning meanings. The unveiling of how different learning experiences generate different levels of impacts on organizations and the proposal of some ways to enhance the transit from less complex learning experiences to more complex ones are the main contribution of this paper.
\end{abstract}

Keywords: Organizational learning. Boundary crossing. Organizational routine. Job rotation. Phenomenography.

\section{Resumo}

O objetivo desse estudo foi compreender como indivíduos experienciam a aprendizagem no trabalho, e lançar luz sobre possíveis fatores que contribuem para um ambiente favorável à aprendizagem nas organizações. A abordagem fenomenográfica foi escolhida com a intenção de capturar a variação nas concepções de aprendizagem dos indivíduos. Os resultados revelaram três concepções: aprendizagem que resulta em mudança individual; aprendizagem que resulta em mudança da prática coletiva (rotina); e aprendizagem que resulta em inovação. Essas concepções foram explicadas por cinco dimensões: conceito de aprendizagem; motivadores da aprendizagem; conteúdo da aprendizagem; método da aprendizagem; obstáculos para aprendizagem; e significado da aprendizagem. Desvelar como diferentes experiências de aprendizagem geram diferentes níveis de impacto nas organizações e apresentar formas de facilitar o trânsito das concepções menos complexas para as mais complexas são as principais contribuições desse artigo.

Palavras-chave: Aprendizagem organizacional. Travessia de fronteira. Rotinas organizacionais. Job rotation. Fenomenografia. 


\section{Introduction}

Work, learning and innovation are processes that are considered to occur interdependently (Gherardi, 2011). However, learning in organizations is not always a smooth process (Argyris, 1991).

In addition to Argyris' remark, the growing corpus of academic studies and training programs focusing on organizational learning (OL) underscores the relevance and the great challenge of learning for organizations (Easterby-Smith \& Lyles, 2011). Pettit, Crossan and Vera (2017) drew attention to the importance of remembering that "individuals - with their characteristics, abilities, choices, motivations, and cognition - are the key building blocks for understanding organizational capabilities and routines" (p. 493), and that this micro-foundation approach can help understand the OL processes. Howard-Grenville and Rerup (2017) find that creativity is an aspect overlooked in the research on organizational routines and that creative routines can help organizations to become more innovative. Studying learning in organizational routines can be a path to achieve creativity and innovation, because, as noted above, work, learning and innovation are processes that are considered to occur interdependently (Gherardi, 2011).

Based on this context, this paper aims to contribute to OL studies by investigating how individuals experience learning and advancing possible factors that foster an environment conducive to learning in the workplace context.

The focus of the dataset of this paper is the moment right after a boundary crossing, as experienced in "job rotation" situations, i.e., a scenario in which changes occur in an employee's functions related to a switch in their area or department, albeit with pay-scale or rank within the company remaining unchanged (Campion, Cheraskin \& Stevens, 1994). The initial assumption is that deploying job rotation sets up a situation of intensive learning in which the individual starts out from a state of ignorance; moreover, this state of ignorance can be an important driver of the learning process. The employee who once was regarded as an expert and knowledge provider, when crossing a boundary (Wenger, 1998) within the organization, suddenly becomes a novice again (Wilkesmann \& Wilkesmann, 2011), and is subject to an intense experience of social and practice-based learning (Brown \& Duguid, 1991), situated in the work actions. As such, the article is based on the principle that organizational routines represent the practice-based learning locus, because such routines are the locus where events transpire develop and work is executed.

The research process is guided by the following question: How do individuals experience social and situated learning in organizational routines involving intensive learning situations, such as a boundary crossing in a job rotation scenario?

To answer this question, a phenomenographic study was conducted (Marton \& Booth, 1997) in which employees from several companies who had experienced a boundary crossing situation were interviewed and invited to report on their livinglearning experienced at that moment.

After analyzing the content of the interviews and following the prescribed method, an outcome space was constructed that represents an original theoretical framework. Although not a planned outcome of the research, the most important contribution of this paper to both theoretical studies and the practice of OL concerns the different levels of impact caused by the different learning experiences.

The paper is divided into seven sections: (1) this introduction; (2) theoretical background; (3) research method; (4) main findings; (5) discussion and some propositions, (6) final remarks, and (7) references.

\section{Theoretical background}

Below, we present the theoretical underpinnings that serve as a reference for the study. The first point presented - the encounter with the unknown - refers to the job rotation process and provides important fundamentals, since it explains the scenario in which the current study was conducted. The second point the transposition - deals with the concept of boundary, which we sought out in the literature on communities of practice. The third point - bridging approaches in OLconcerns the approaches to OL that intermesh with the object of study of this research. The last point - where the learning experience takes place - presents a basic reference on important organizational routines for this study, insofar as it is in the context of organizational routines that practice-based learning occurs.

\section{The encounter with the unknown}

An ongoing challenge to the academic literature 
on managerial development has been the study of instances that facilitate the learning process (Wexley \& Baldwin, 1986; Goldman, Scott \& Follman, 2015).

One of the tools in experimental or practical perspectives on human resources development is job rotation. To correctly define this concept, it is necessary to establish certain differences in relation to other organizational practices. Firstly, job rotation does not entail a promotion or change in level, added responsibilities, and an increase in pay and/or benefits. On the other hand, job rotation is considered a form of career development, and is regarded by upper management as a way to reward good performance (Campion et al., 1994).

Eriksson and Ortega (2006) list three concepts that shape the implementation of a job rotation program: employee learning, employer learning, and employee motivation. Employee learning refers to employees becoming more versatile and experienced after acquiring new skills and experiences in a new workplace context. Employer learning consists of the company's knowledge acquired vis-à-vis employees, after watching them perform in different roles. Lastly, employee motivation relates to the employee performing tasks that are more interesting and less repetitive.

The dynamics of job rotation provide participants the opportunity to cross boundaries within the organization, and this in itself brings more possibilities for learning since such a movement means an encounter with the unknown (Wenger, 2000). The encounter with the unknown leads the individual to a state of ignorance. According to the typology of ignorance proposed by Roberts (2012), some types of ignorance can create value for the individual and for the organization because they trigger the search for new knowledge. These types of ignorance - "known unknowns" and "knowable known unknowns" (Roberts, 2012, p. 227) - are the ones that seem to be present in the job rotation situation, where individuals are aware of their state of ignorance. At the same time, as a new element of a social system prompting a new view, the individual experiencing a job rotation condition may reduce other types of ignorance previously existing in the group that bring losses for the organization, i.e., the "taboos" and the "denials" (Roberts, 2012, p. 227).

Because crossing boundaries may create a state of ignorance that triggers the search for new knowledge, understanding the relationship between such a movement and learning becomes necessary. To facilitate this understanding, the next sections present, respectively, concepts related to studies on communities of practice and approaches to organizational learning.

\section{The transposition - communities of practice and boundary}

Communities of practice (CoPs), the constitutive elements of social learning systems, keep the competences that move such systems (Wenger, 2000). The boundaries of communities of practice are formed from the nature of shared practice (Wenger, 2000). That is, a CoP defines its limits through the nature of the practice performed by its members and keeps outside its boundaries, or on the periphery, individuals who do not share the same practice. This definition may imply a negative connotation for the term "boundary," because it evokes a notion of limit, exclusion, or lack of access (Wenger, 1998, 2000; Wenger, McDermott \& Snyder, 2002). However, when properly understood, boundaries can be seen as a source of new opportunities. Interacting beyond their own practice allows CoP members to look beyond their own presuppositions. Consequently, crossing a boundary may be an important source of learning, because new insights may result from this type of interaction (Wenger et al., 2002). This learning process occurs from the tension, or distance, established between experience and competence (Wenger, 1998), since, while deep expertise rests on the convergence of experience and competence, innovative learning demands their divergence (Wenger, 2000). Because of this dynamic, the moment of crossing a boundary when the experience drifts away from the competence or when an expert becomes a novice (Wilkesmann \& Wilkesmann, 2011) - can be considered an intensive learning moment. As such, how does this transposition occur?

Three types of bridges can be established between boundaries: people, objects, and different forms of interaction. Some people act as brokers between communities, engaging in actions of "import-export," introducing knowledge or other elements from one practice into another. Some objects are of value not only for a single practice, but mainly because they support connections between different practices. Such objects can be artifacts, for example, tools, 
documents or models shared by different practices, discourses or a common language, and processes shared by different practices, e.g., explicit routines or procedures (Wenger, 2000).

The study of CoP boundary dynamics fosters an understanding of how learning can be activated in organizations - especially in the context of job rotation, a scenario that may be understood as an opportunity for boundary crossing. But, for a consistent investigation of what is learned in this context and how such learning occurs, familiarity with some of the approaches in the literature regarding OL is important.

\section{Bridging approaches in organizational learning}

An issue in recent studies on OL has been the bridging between the epistemologies of possession and of practice (Cook \& Brown, 1999), which may engender a more thorough view of the phenomenon. A crucial impulse of this movement was the study by Cook and Brown (1999). Following that movement, Elkjaer (2004) proposes a third approach, which comes from the pragmatic theory of learning, especially the concepts of inquiry and the experience of John Dewey. Inquiry begins when the individual faces a situation of uncertainty and works to solve it, using thinking as a tool to investigate and seek a solution (Elkjaer, 2004). Experience is the transactional movement between the individual and the environment, where each influences the formation of the other (Elkjaer, 2004). According to Dewey (1916 [1981]), the learning experience assumes two moments: the active moment (trying) and the passive moment (undergoing), the outcome created by the experience. These concepts contribute to the understanding of what happens at the clash of the apprentice with the day to day of the organization and the work practice, and tend to involve both the content (the experience) and the process (inquiry) of learning (Elkjaer, 2004). In a later paper, the author "renames" the three approaches and sums up the characteristics of each.

According to the first approach - the theory of individual learning - learning is the improvement of the individual mental model, also referred to as "cognitive structures," and happens by acquiring new knowledge that can guide individual behavior and, consequently, organizational behavior (Brandi \&
Elkjaer, 2011). The second approach - theory of social learning - emphasizes informality, improvisation and collective action. There is a fundamental distinction between learning and intentional instruction (Lave \& Wenger, 1991). In this approach, learning is not the acquisition of known knowledge, but the process of moving towards the unknown and a way to become part of the community of practice that constitutes the organization, with the main objective of becoming a competent practitioner (Brandi \& Elkjaer, 2011). The third approach - pragmatic learning - is aligned with the philosophy of the theory of social learning, but does not disregard the individual capacity to investigate (inquiry) and construct new organizational experiences during the process of OL (Brandi \& Elkjaer, 2011).

Parallel to the third approach, Gherardi (2011) argues that OL happens as an activity situated in work practices; and the organizational activity itself organizing - must be seen as a learning process.

When the OL is seen through the lens of pragmatic learning, it is important to understand the relationship between learning and organizational routines, since routines (practice) become the locus of the learning experience in the organizational context.

\section{Where the learning experience takes place}

Organizational routines are "repetitive, recognizable patterns of interdependent actions, carried out by multiple actors" (Feldman \& Pentland, 2003, p. 95), and consist of two dimensions: the ostensive aspect, which refers to the structure, and the performative aspect, which refers to the manner in which the routines happen through the action of the individuals who carry them out (Feldman \& Pentland, 2003).

Stated otherwise, the ostensive aspect is the abstract understanding of the routine, "the abstract patterns that participants use to guide, account for and refer to specific performances of routine" (Pentland \& Feldman, 2005, p. 795). It must be kept in mind, however, that although this statement can be used to guide, it should not be characterized as a single, stable, standard procedure. One factor contributing to understanding this dynamic is the multiple interpretations regarding the ostensive aspect, which relies, among other factors, on the various points of view of the individuals involved in executing a 
single task (Feldman \& Pentland, 2003; Feldman \& Orlikowski, 2000).

The performative aspect of routine can be considered synonymous with performance, defined as "specific actions, by specific people, in specific places and times" (Feldman \& Pentland, 2003, p. 102).

The ostensive and performative aspects of the routine are mutually constitutive (Parmigiani \& HowardGrenville, 2011). Considering the interaction between its different actors, a routine cannot be considered static; therefore, its dynamics can unleash greater or lesser flexibility, resulting in greater stability or orientation to change, depending on the circumstances in the context (Pentland \& Feldman, 2005).

The practical approach of the routine - which is the one that matters for this study - emphasizes individual agency, i.e., the ability to make adaptations to routines given that external contingencies may influence their execution. Thus, aspects of the performative dimension - meaning the way by which individuals establish their actions - may be responsible for changing the ostensive aspect of the routine. Such changes may stem from the need for different actors, whether involved in the routine or from external determinations (Feldman \& Pentland, 2003).

\section{The path followed - the research method}

Since the object of study of this research is the learning experience, a method suitable to the study of variations of experience from the standpoint of those who have experienced it was sought. Therefore, the chosen method was phenomenography.

Because the object of study of phenomenography is the "variation in ways of experiencing phenomena" (Marton \& Booth, 1997, p. 111), the selection of participants aimed to ensure the required range (Green, 2005). Regarding quantity, a sample of 20 subjects was interviewed, a number sufficient to obtain the required variety, yet one not likely to produce an excessive volume of data to perform an analysis with the appropriate quality (Bowden, 2005).

The sample selection was conducted in different companies, which enabled the collection of distributed data (Howard-Grenville \& Rerup, 2017) among people with diverse characteristics who have experienced situated learning in organizational routines within a job rotation situation. Table 1 describes the sample.

Table 1 . Sample description.

\begin{tabular}{|c|c|c|c|}
\hline & $\begin{array}{l}\text { Company } \\
\text { Sector }\end{array}$ & From & To \\
\hline I1 & $\begin{array}{l}\text { Government } \\
\text { Regulation } \\
\text { Agency }\end{array}$ & $\begin{array}{l}\text { General } \\
\text { manager of } \\
\text { aeronautical } \\
\text { product } \\
\text { certification }\end{array}$ & $\begin{array}{l}\text { General } \\
\text { manager of } \\
\text { continuing } \\
\text { airworthiness }\end{array}$ \\
\hline $\mathrm{I} 2$ & Telecom & $\begin{array}{l}\text { Internal HR } \\
\text { consultant in } \\
\text { marketing } \\
\end{array}$ & $\begin{array}{l}\text { Business } \\
\text { Partner } \\
\text { management } \\
\end{array}$ \\
\hline I3 & $\begin{array}{l}\text { Government } \\
\text { Regulation } \\
\text { Agency }\end{array}$ & $\begin{array}{l}\text { Continuing } \\
\text { Airworthiness } \\
\text { - technical } \\
\text { guidelines } \\
\end{array}$ & $\begin{array}{l}\text { Airworthiness - } \\
\text { supervision and } \\
\text { certification }\end{array}$ \\
\hline I4 & $\begin{array}{l}\text { Government } \\
\text { Regulation } \\
\text { Agency } \\
\end{array}$ & $\begin{array}{l}\text { Navigability } \\
\text { - General } \\
\text { aviation }\end{array}$ & $\begin{array}{l}\text { Navigability - } \\
\text { Operational }\end{array}$ \\
\hline I5 & $\begin{array}{l}\text { Government } \\
\text { Regulation } \\
\text { Agency } \\
\end{array}$ & $\begin{array}{l}\text { Program } \\
\text { Management } \\
\text { (projects) }\end{array}$ & $\begin{array}{l}\text { Engineering } \\
\text { Management }\end{array}$ \\
\hline I6 & $\begin{array}{l}\text { Government } \\
\text { Regulation } \\
\text { Agency }\end{array}$ & $\begin{array}{l}\text { Coordination } \\
\text { Manager }\end{array}$ & $\begin{array}{l}\text { Maintenance } \\
\text { engineering } \\
\text { manager }\end{array}$ \\
\hline I7 & $\begin{array}{l}\text { Government } \\
\text { Regulation } \\
\text { Agency } \\
\end{array}$ & $\begin{array}{l}\text { Engineering } \\
\text { Management }\end{array}$ & $\begin{array}{l}\text { Management } \\
\text { of Certification } \\
\text { Programs }\end{array}$ \\
\hline I8 & $\begin{array}{l}\text { Government } \\
\text { Regulation } \\
\text { Agency }\end{array}$ & $\begin{array}{l}\text { General } \\
\text { manager of } \\
\text { continuing } \\
\text { airworthiness }\end{array}$ & $\begin{array}{l}\text { General } \\
\text { manager of } \\
\text { aeronautical } \\
\text { product } \\
\text { certification } \\
\end{array}$ \\
\hline I9 & Telecom & \begin{tabular}{|l} 
Human \\
Resources \\
Management \\
\end{tabular} & \begin{tabular}{|l} 
Human \\
Resources \\
Development
\end{tabular} \\
\hline $\mathrm{I} 10$ & Telecom & $\begin{array}{l}\text { Customer } \\
\text { Operations }\end{array}$ & Marketing \\
\hline $\mathrm{I} 11$ & Energy & Planning & Operational \\
\hline $\mathrm{I} 12$ & $\begin{array}{l}\text { Food and } \\
\text { Beverage }\end{array}$ & $\begin{array}{l}\text { Marketing } \\
\text { Brazil }\end{array}$ & Marketing Peru \\
\hline $\mathrm{I} 13$ & Telecom & \begin{tabular}{|l} 
Human \\
Resources \\
Development \\
\end{tabular} & $\begin{array}{l}\text { Business } \\
\text { Management }\end{array}$ \\
\hline $\mathrm{I} 14$ & Financial & \begin{tabular}{|l|} 
Office of \\
credit (Oil \\
and gas \\
sector) \\
(Brazil) \\
\end{tabular} & \begin{tabular}{|l} 
Financial \\
advisory \\
services for \\
companies \\
(Amsterdam) \\
\end{tabular} \\
\hline $\mathrm{I} 15$ & Education & \begin{tabular}{|l} 
HR \\
Management \\
\end{tabular} & $\begin{array}{l}\text { HR Business } \\
\text { Partner }\end{array}$ \\
\hline $\mathrm{I} 16$ & Telecom & Projects & Marketing \\
\hline
\end{tabular}




\begin{tabular}{|l|l|l|l|}
\hline I17 & Telecom & Training & $\begin{array}{l}\text { HR } \\
\text { Management }\end{array}$ \\
\hline I18 & Tobacco & Operational & $\begin{array}{l}\text { Human } \\
\text { Resources }\end{array}$ \\
\hline I19 & Telecom & $\begin{array}{l}\text { HR- Internal } \\
\text { consultant }\end{array}$ & $\begin{array}{l}\text { HR - } \\
\text { Remunaration }\end{array}$ \\
\hline I20 & Telecom & $\begin{array}{l}\text { Recruitment } \\
\text { and selection }\end{array}$ & Management \\
\hline I21 & Telecom & $\begin{array}{l}\text { Human } \\
\text { Resources } \\
\text { Management }\end{array}$ & $\begin{array}{l}\text { Human } \\
\text { Resources } \\
\text { Development }\end{array}$ \\
\hline
\end{tabular}

Developed by the authors.

Data analysis was done based on the transcripts of the interviews, starting with a content analysis process, which grouped the content by the edges, separating first the most contrasting contents and then those with similarities. At the same time, differences within each group were identified. This was an iterative process, alternating between the whole and the parts, between "what" and "how," until each group was stable, as suggested by Schembri and Sandberg (2011). At the end of this content analysis process, several descriptive categories emerged, which, following the proposals of Akerlind (2005b), had not been determined in advance; indeed, they emerged from the relationship between the data and the researchers, during the process of searching for similarities and differences and identifying the most significant criteria that would explain the differences, i.e., the explanatory dimensions. The researchers' perception of variations built from this cycle of iterations shed light on the collective experience of the phenomenon in a holistic way (Âkerlind, 2005), which was attained from the logical structure built from the organization of the descriptive categories; the so-called outcome space, in terms of phenomenography. The outcome space comprises the logical relationship (architecture) established between the descriptive categories, structured from the least to the most complex categories (Marton \& Booth, 1997). The construction of the outcome space was the last step in the data analysis process within the scope of the research, and can be considered the major contribution of the applied method to the knowledge creation process.

\section{Field disclosures - main findings}

The findings presented here represent the result of an iterative process of data collection, analysis and literature review, developed in an abductive process. The analysis cycle sought to unveil the learning experience in the context of the participants' workplace, based on their report of this experience. From the first analysis, a set of six explanatory dimensions was established which were used as a basis to understand how learning occurred during the job rotation scenario experienced by the interviewees: (1) learning concept; (2) what drives learning; (3) what they learn; (4) how they learn; (5) what hinders learning; (6) what learning represents. Such explanatory dimensions appeared naturally in the discourse of the interviewed group and became the first pattern noticed in the set of interviews.

The perception of the researchers regarding the variations shown in these six dimensions led to our identifying three descriptive categories of the learning process experienced, through the process of organizing the interviews content into the six dimensions. Within each dimension, we found three different groups (or three variations in the way of experiencing learning), which became the three descriptive categories: the learning process that results in individual change; the learning process that results in collective practice (routine) change; and the learning process that results in innovation. After the process of distributing the content through the six dimensions, it became clear to the researchers that the most significant difference between the three descriptive categories was the impact of the learning process, i.e., where the definition of the names of the categories came from. This categorization is related to Dewey's concept of experience, which assumes an active moment (trying) and the passive moment, the outcome (Dewey (1916 [1981]) - showing that for each different process of trying there is a different outcome.

The three descriptive categories show the three conceptions regarding learning in a workplace context that were noticed by the researchers in the group interviewed. Going forward, we will speak of the descriptive categories and conceptions synonymously.

The process of revealing the conceptions by the researchers will be highlighted by means of the quotes presented in this section.

Table 2 summarizes these findings. 
Table 2 . Outcome Space - Relationship between Descriptive Categories and Explanatory Dimensions.

\begin{tabular}{|c|c|c|c|}
\hline \multirow{2}{*}{$\begin{array}{l}\text { EXPLANATORY } \\
\text { DIMENSIONS }\end{array}$} & \multicolumn{3}{|c|}{ DESCRIPTIVE CATEGORIES | CONCEPTIONS } \\
\hline & $\begin{array}{l}\text { Learning process that results } \\
\text { in individual change }\end{array}$ & $\begin{array}{l}\text { Learning process that results } \\
\text { in collective practice (routine) } \\
\text { change }\end{array}$ & $\begin{array}{l}\text { Learning process that } \\
\text { results in innovation }\end{array}$ \\
\hline Learning concept & $\begin{array}{ll}\text { - } & \text { Knowledge acquisition } \\
\text { - } & \text { Edaptive learning } \\
& \text { Epistemology of } \\
\text { possession }\end{array}$ & $\begin{array}{l}\text { Knowing in the experience of } \\
\text { new practices } \\
\text { - Generative learning - } \\
\text { internal - routines change } \\
\text { - Epistemology of practice }\end{array}$ & $\begin{array}{l}\text { - } \text { Generation of new } \\
\text { practices, products or } \\
\text { services - new solutions } \\
\text { - } \text { Generative Learning - } \\
\text { external - innovation } \\
\text { - Epistemology of } \\
\text { practice }\end{array}$ \\
\hline What drives learning & $\begin{array}{l}\text { Ignorance - related to } \\
\text { know-what, know-how } \\
\text { (ostensive aspect of the } \\
\text { routines) and know-who }\end{array}$ & $\begin{array}{l}\text { Ignorance - related to how } \\
\text { to interact with new teams, } \\
\text { how to act in the routines } \\
\text { (performative aspect of the } \\
\text { routines) }\end{array}$ & $\begin{array}{l}\text { Ignorance - related } \\
\text { to the new context } \\
\text { (market), to the client's } \\
\text { demands, and to the } \\
\text { emerging complex } \\
\text { problems }\end{array}$ \\
\hline What it learns & $\begin{array}{l}\text { Learning to be [self- } \\
\text { knowledge, to deal with } \\
\text { ignorance, fear and } \\
\text { challenge] } \\
\text { Learning to know [know- } \\
\text { what - technical } \\
\text { knowledge, conceptual } \\
\text { knowledge; know-how - } \\
\text { new routines (ostensive } \\
\text { aspect); and know-who - } \\
\text { who knows what] }\end{array}$ & $\begin{array}{l}\text { - Learning to live together } \\
\text { [empathy, learning to listen, } \\
\text { learning to bond in the team] } \\
\text { - Learning to do [new } \\
\text { routines (performative } \\
\text { aspect) and improvements } \\
\text { implementations] }\end{array}$ & $\begin{array}{l}\text { - Learning to live together } \\
\text { [empathy, learning to } \\
\text { listen, learning to bond - } \\
\text { with client] } \\
\text { - Learning to know [know- } \\
\text { what - the inner context } \\
\text { (in case of an internal } \\
\text { client) or the market } \\
\text { (in case of an external } \\
\text { client); and know-who - } \\
\text { who is the client] } \\
\text { Learning to do [new } \\
\text { solutions generation and } \\
\text { implementation] }\end{array}$ \\
\hline How it learns & $\begin{array}{l}\text { Through inquiry - about } \\
\text { the know-what and the } \\
\text { ostensive aspect of new } \\
\text { routines } \\
\text { - Through manuals, } \\
\text { procedures (artifacts) } \\
\text { - Through other people }\end{array}$ & $\begin{array}{l}\text { - Through inquiry - about the } \\
\text { performative aspect of new } \\
\text { routines } \\
\text { - Through performing in the } \\
\text { routines } \\
\text { - Through reflection after } \\
\text { mistakes } \\
\text { - Through exercise and tasks } \\
\text { repetition } \\
\text { - Through the interaction } \\
\text { with other people and with } \\
\text { artifacts }\end{array}$ & $\begin{array}{l}\text { - Through inquiry - about } \\
\text { the client's problems } \\
\text { - creating empathy, } \\
\text { listening } \\
\text { - Through problem } \\
\text { solving } \\
\text { - Through the interaction } \\
\text { with clients }\end{array}$ \\
\hline $\begin{array}{l}\text { What hinders } \\
\text { learning }\end{array}$ & $\begin{array}{l}\text { - Lack of interest in the } \\
\text { activity } \\
\text { - Rigid mental model } \\
\text { - Lack of formal training } \\
\text { - Unavailability of } \\
\text { colleagues to help }\end{array}$ & $\begin{array}{l}\text { - Deficiency in interaction and } \\
\text { in communication } \\
\text { - "Gabriela Syndrome" - It's } \\
\text { always been done this way }\end{array}$ & $\begin{array}{l}\text { - Dysfunctions in } \\
\text { bureaucracy - "chains" } \\
\text { - Excessive instability } \\
\text { (provoked by the state } \\
\text { of ignorance imposed by } \\
\text { job rotation) }\end{array}$ \\
\hline
\end{tabular}




\begin{tabular}{|l|l|l|l|}
\hline $\begin{array}{l}\text { What learning } \\
\text { represents }\end{array}$ & $\bullet \begin{array}{l}\text { Perceived value focused on } \\
\text { the individual } \\
\begin{array}{l}\text { Personal and professional } \\
\text { growth }\end{array}\end{array}$ & $\begin{array}{l}\text { Productivity gains } \\
\text { Collective experience } \\
\text { acquisition }\end{array}$ & $\begin{array}{l}\text { New results } \\
\text { Security increase } \\
\text { Achievement capacity }\end{array}$ \\
\hline
\end{tabular}

Developed by the authors.

\section{First conception - Learning that results in individual change}

The first category points to the notion that learning in the workplace is a process that results in individual change. This conception - the least encompassing and complex of the three - is based on the idea that learning means acquiring knowledge and traces back to the epistemology of possession (Cook \& Brown, 1999), wherein knowledge is something that people possess, and emphasis lies in explicit, individual knowledge. The following quotation illustrates this concept of learning:

[Learning is] the process of acquiring and constructing new knowledge, from experiences, encounters and theoretical knowledge; but it is [also] to capture, to learn of a new thing and store it in the repertoire of knowledge that has already been learned. (I15)

Besides the notion of acquiring something new, the quote illustrates the notion of the individual benefit of learning. There is no necessary direct impact of this learning beyond the learner. Following this perception, what motivates people to learn are internal impulses related to feelings that boundary crossing creates. At the moment of job rotation, people feel ignorant, scared and challenged. In their previous positions, they were considered experts; but when they assumed new roles, they felt like novices again (Wilkesmann \& Wilkesmann, 2011). In this situation, ignorance can be understood as an important motivator for learning. The following quotation illustrates this notion:

So [not having the necessary knowledge] creates some discomfort; I feel inept. (I12)

The need to establish a trusting relationship with their peers, bosses and subordinates is another factor that can promote learning in this conception.

I feel motivated because in my previous area I had already mastered... I already had a position commanding a certain respect. And now, it's like I'm starting, not from zero, (because, as I said, I have already matured in terms of my professional stance) but the knowledge required for the activity itself — I don't have it — I haven't mastered it. So, it motivates me in the sense that I need to conquer, to go after that all over again so that I can earn the same respect, or some security. (I11)

What can be gathered from this statement is that the security the interviewee is seeking will foster the trust and respect of her peers with respect to her. This drives her to "go after" learning about the new activities. In addition, the encounter with the unknown (Wenger, 2000) and the distance between competency and experience (Wilkesmann \& Wilkesmann, 2011) seems to work as a motivator for the employee, which Eriksson and Ortega (2006) point out as important result of the job rotation process.

Another dimension that helps to explain this conception is the content of the learning process. The content mentioned, related to this conception, may be categorized based on two of the Four Pillars of Learning 
proposed by UNESCO (United Nations Educational, Scientific and Cultural Organization): Learning to be and learning to know (Delors, 1996).

The learning to be relates to self-knowledge and identity formation, and the learning to deal with ignorance, fear and challenge can be included in this category. In a job rotation situation, the crossing of an (internal) organizational boundary engenders, as was shown, a scenario of ignorance, fear and challenge in the employee (Roberts, 2012), who must learn to deal with these new feelings that did not exist - or that existed to a lesser extent - in their previous position. Learning to deal with these feelings may convert them into an added boost for learning, as exemplified by the following interviewee quote:

It's not just technical knowledge; it's also behavioral knowledge of my way of acting, my awareness of my limits and weaknesses as a person. The process of job rotation brings about all of this in you. [...]. So, it's also part of personal growth. (I9)

Learning to know, in this conception, concerns the development of know-what, know-how and knowwho. They are learnings built by the individual during job rotation that aim to minimize their state of ignorance in the new workplace context, which represents a "known unknown" (Roberts, 2012, p. 227). The individual must search for ways to learn new concepts, new modes - new routines - and new people. The following quotation demonstrates this need:

So, I had to know the process, know exactly what was the area, [and] its objectives, which were completely different from my old area. (I20)

In the first descriptive category of the learning process during job rotation, the content learned is related to knowledge and processes that are already known by other people. As such, this learning constitutes "adaptive learning" (McGill, Slocum, Jr. \& Lei, 1992), the focus of which is restricted to explicit knowledge and learning geared to the ostensive aspect of routines
(Feldman \& Pentland, 2003) previously performed by other people. This learning occurs by inquiry (Elkjaer, 2004), which can be done through artifacts - manuals, procedures, process maps, systems, etc., or through dialog with others, as the following interviewee indicates:

Besides asking, inquiring and
trying to get my questions
answered, I feel a need to know,
to read any explanatory document
that establishes the rules, or to
read up on the subject so that I
feel a bit more sure about what
I'm doing. (I11)

Some factors may, however, hinder that process. Lack of interest in the activity exercised may lead to difficulty in finding the knowledge required for its accomplishment. Interviewee \#19 puts it as follows:

I have to execute activities within my scope, generally; but I have no aptitude for, or personal interest in them; so, at times it's like I was somewhat resistant to mastering the knowledge I had to have. (I19)

Because learning is done through inquiry, based on documents and conversations with others, two aspects may interfere in that process: the feeling of "not wanting to bother coworkers with one's questions" and "the unavailability of coworkers to help." (I11)

Interviewee \#20 states that undergoing training could lessen the problem of depending on other people, but that, when there is no formal training, learning may actually be costlier.

Maybe what made it a bit harder was the question of training: there is none. The thing about SAP, for example, is that I often had to stop and ask, and disturb other people's work, in order to perform an activity; whereas if I'd had two, three days training — it would've been much quicker. (I20) 
The last dimension that characterizes this category is what learning represents. According to that conception, learning has a perceived value that focuses on the individual and basically manifests as personal and professional growth. When questioned about what the learning experience during job rotation represented, an interviewee answered:

"I think it represents a stage in the evolution of my career." (I14)

\section{Second conception - Learning that results in the change of collective practice (routine)}

The second category points to the notion that learning in the workplace context is a process resulting in a change of collective practices, or routines. This moderately encompassing conception is based on the idea that learning, or knowing, happens in the practice located in organizational routines. This conception is aligned with the epistemology of practice (Cook \& Brown, 1999), whereby knowing is understood as an action in individual or group practice and is shaped as an aspect of the interaction between people and the physical and social world (Cook \& Brown, 1999; Gherardi, 2011). In this conception, learning is active - because it happens in action - and "generative" (McGill et al., 1992) - because it implies the transformation of the practice or the creation of new practices within the organizational routines. Some interviewees showed an understanding of learning within this conception, which is illustrated in the following quotation:

Now I have the opportunity to
join the processes and understand
the cycle of an approval process
[the approval process is an
organizational routine] ... including
discussing with my team managers
how to improve the processes -
which is what we're looking for
right now. (I1)

Since the focus here is on learning that occurs in, and may modify, collective practice, the trigger that drives this learning comes from the context of the interaction with others. The ignorance related to the modus operandi in unfamiliar situations showed up as the main factor driving learning within this conception, and indicates a strong relation with the entry into a new Community of Practice with the main objective of becoming a competent practitioner (Brandi \& Elkjaer, 2011).The focus is not on conceptual/ theoretical ignorance, nor on the ostensive aspect of the organizational routine, but on not knowing how to perform in an unfamiliar situation. This ignorance can be linked to relational aspects - how to act with a certain person or group; or to decision-making aspects - what to do. If, in the previous conception, ignorance was related to knowledge, in this conception, it relates to knowing.

The following excerpt indicates how this ignorance manifests:

\begin{abstract}
[Before] I already knew what to do in situations as they arose; I'd been through most of them; then when confronted by similar situations, I was much more confident. But there's the deal with insecurity, a certain angst surrounding new situations, right? "Now what do I do?", "How do I do this?", "Wow! I never knew I'd be facing this sort of thing." (I4)
\end{abstract}

The state of ignorance that takes hold after crossing the boundary in a job rotation situation drives the learning of different content. According to the Four Pillars of Learning (Delors, 1996), learning in this conception is of two types: learning to live together and learning to do.

Learning to live together relates to "the development of the comprehension of the other and the perception of interdependences" (Delors, 1996, p. 31). The content of the interviews showed us the development of three principal skills related to this learning: empathy; knowing how to listen; and knowing how to establish connections (knowing how to relate to others).

The development of empathy was one of the main lessons learned by individuals who had undergone job rotation. Listening to and understanding the other, putting oneself in someone else's shoes, and trying to do things that favor the other were constant lessons in the experience of several interviewees, especially those who had switched areas or positions in relation 
to internal clients or suppliers.

We had that view, like, "Well, that area doesn't work properly; that area doesn't think about everything..." Now that I'm on this side, I see it's not how I thought it was. (I16)

Knowing how to listen, which can be considered the first step in the development of empathy, was also emphasized in interviews. One example is this quotation from interviewee \#7:

I've had the opportunity of exercising, shall we say, the ability to listen to people, to establish connections and try to understand their difficulties ... in order to make things work ... so, to me, it was great. (I7)

The notion that actions, within and between routines, happen interdependently (Feldman \& Pentland, 2003) leads to the need to learn to establish bonds, taking into consideration people's differences. Such a need was present in the accounts of various interviewees, for example:

But here I'm learning to deal with another culture, right? So, I learn every day what to say, what not to say, how to say it, what I've been saying, what tends to be more sensitive or wrongly interpreted... And I - because Brazilians talk and gesture a lot and tend to be really emphatic and incisive sometimes I touch people, and I learned not to touch them, especially when they are men, I go through this type of learning every day. (I12) [a case of international job rotation]

Learning to do relates to the development of "competence that enables people to deal with a variety of situations, often unforeseeable, and to work in teams," (Delors, 1996, p. 31). Within this conception of learning, learning to be able to face new situations and perform and improve new routines is key. When analyzing the interview content, it was noticed that, as job rotation offers the newcomer to the position a new perspective on routines, the modality favors an environment conducive to generating new practices, and consequently the learning of other members of the team, creating conditions to reduce other types of ignorance previously existing in the group, such as "taboos" and "denials" (Roberts, 2012, p.227)

The following excerpt shows that, when she changed positions, interviewee \#13 noticed a longstanding problem and proposed a new routine in order to mitigate that problem - something that had not been tried prior to her arrival.

I think now we're implementing a routine that's been demanded of us for a long time, something we often hear about from our clients, that HR is too distant ... So the idea is to hold, at least twice a month, a meeting with professionals from the boards of directors, whether separate or mixed, all the boards mixed, or just a single board. That's becoming a routine we're implementing, I've managed to build two groups since I've gotten here. (I13)

Since the content of learning referred to here is performance in new routines, and this conception of learning relates to the epistemology of practice (Cook \& Brown, 1999; Elkjaer, 2004; Gherardi, 2011), learning could happen in no other way than through actually performing the routines. If in this case the focus is on knowing (as mentioned above), and knowing manifests in practice, it can be said, to put it succinctly, that people "learn by doing," i.e., learn by experience, as stated by Dewey (1916[1981]).

Performance of the routines - which involves accomplishing tasks, making mistakes, inquiring about the performative aspect of routines (which can occur through observation, for example), and interacting with people and with artifacts - is how learning to do occurs.

We had to bring up the case again, discuss it once more, reverse a decision that was previously agreed 
upon and obtaining the agreement of the director. So, for me, I learned that you can't decide on topics without previously discussing them, because that won't work; so, from then on, that was useful for the rest of the topics I brought up in that meeting. (I18 - about a routine involving periodic meetings with a certain group)

Since this learning process anticipates interaction between people - because practice in routines happens collectively and interdependently (Feldman \& Pentland, 2003) - a hindering factor may be a deficiency in interaction and in communication. One of the reasons pointed out by the interviewees for such shortcomings was the lack of availability of key individuals to help them learn, as the following excerpt illustrates:

Since you need what's shared. It's fundamental for the learning process: You can find yourself in a situation where people - and that still happens - they consider having that knowledge as some sort of power — as though — as long as they retain that knowledge - if they were to share it - they would weaken themselves - perhaps because they would stop appearing as important as others who have that knowledge. Right? ... So, it's an obstacle in places where this is the mindset. (I9)

Another aspect considered a hindrance towards learning to do, or, more specifically, of generating transformation or improvements in routines, is the "it's always been like this" thinking, as an interviewee points out in the following excerpt:

Sometimes doing the same thing doesn't work, because it's like this: "Oh, it's always been done this way." When I went through different areas, people would always say, "But it's always been like this here." So, I'd ask why. And it was always, "It's always been done this way." It doesn't work because it blocks innovation; things could be more efficient... (I17)

All the dimensions that characterize this conception of learning refer to learning, or to change in the practice of organizational routines in their performative aspect. As such, the impact of such learning relates to productivity gains, to the acquisition of collective experience, and to the increase of security and capability for achievement. Such are the values perceived by the interviewees that were generated by learning within this conception.

\section{Third conception - Learning that results in innovation}

This category, the most encompassing of the three categories, is based on a conception of generative learning (McGill et al., 1992) as a process to generate new solutions - whether a new practice, a new product, or a new service. In this conception, the focus is turned on the client - internal or external - and they become the point of interest and the motivator for the process of learning and innovation. The following excerpt illustrates this idea:

Now we'll have to innovate, as in
create new things - not changing
what already exists in order to try
and increase efficiency... We will
literally have to create new things.
... Because the society itself (the
client), by means of the industry
(regulates) is trying to come
through ... They feel the need for
that to evolve, because the system
is completely saturated. (I7)

Once again, the state of ignorance will trigger the learning process. In this case, ignorance relates to knowledge about the client, their demands and problems. It also involves knowing the inner context (in case of an internal client) or the market (in case of an external client), which also represents a "known unknown" (Roberts, 2012, p. 227) However, in this conception, the interest does not lie solely in knowing 
the context/market and the client. The aim is to create new solutions that better suit the demands and solve problems with more efficacy. In this regard, interviewee \#14 talks about the need to understand each client, each demand, and each reality:

The work that I do is very nuanced. Each case is different; each financial structure is different; each client company is different. So, each company has a different situation, different demands, different characteristics. In a way, every business or business opportunity that you look at is different and you'll have to learn something. (I14)

The content of learning within this category encompasses three basic learnings: learning to know, learning to live together, and learning to do (Delors, 1996). Learning to know, in this case, focuses on the knowwhat - suited to the customer/market - and knowwho - suited to the client. However, just learning about the client is not enough. It is necessary to learn to relate to the client, to coexist with them. In fact, the learning about the client and the learning to coexist with the client co-occur, in an integrated manner, since it is during the practice of this relationship with the customer that learning about them occurs - once again, learning occur through experience (Dewey (1916[1981]). Building empathy is crucial to this process. Interviewee \#1 points out the need to learn about the market after his change in area:

It's a market I hadn't had much contact with. So, when you don't have any contact with it, you don't know its needs. As soon as I entered management, I started acquainting myself with the difficulties of these people... I learned a lot. (I1)

Learning to do can be understood as a crucial lesson in this category, since it is a process that results in innovation. Learning to generate and implement new solutions is the main content of learning within this category. But how does this learning process happen?

From the interviewees' perceptions and consistent with the literature on situated learning and the epistemology of practice (Cook \& Brown, 1999; Elkjaer, 2004; Gherardi, 2011), this learning process happens within the very practice of generating and implementing solutions - inquiring about problems, creating solutions, testing, making mistakes, testing again, getting it right. Inquiry, which begins when the individual faces a situation of uncertainty (Elkjaer, 2004), in this case, aim to investigate the problem to be solved, its causes, and its stakeholders, and happen through the interaction with clients, peers, specialists, and others who may contribute to understanding the problem. Interviewee \#18 tells how he approached becoming familiar with his new negotiation routine with the unionists (the "client", in this case):

First, I had six months to know who the people related to that were, what was the dynamic. [...]... I met people, received some input from managers that were participants in the negotiating process. I understood who those people were, their demands, what they really wanted and what could be negotiated. ... Then, after six months, I managed to sit down calmly and reach out for some support. I got support from the labor relations area to help me with the content during that first year - with the technical aspects that I needed to learn in order to negotiate. (I18)

Testing, making mistakes, testing again and getting it right are part of the problem-solving process or the implementing of new solutions. Interviewee \#5 tells of his experiences implementing a new process that broke the current paradigm regarding providing services:

We were trying to change the paradigm so that the company instead of the individual would be certified ... This model, which is the same as in other countries ... left everyone very insecure. [...] We found we'd have to go back. So now we're trying to rebuild, to get the remaining pieces and rebuild the business, keeping the same 
direction but doing it differently, involving the people now. [...] So, it was a hard lesson, a mistake in management. But even so, we learned. (I5)

It is noticeable from these excerpts that, in this conception of learning, the word "we" is far more frequent than "I", as was the case in the first conception. This collective presence exists from the need imposed by the very process of creating and implementing new solutions, because it is necessary to know all the stakeholders involved in the problem, and to listen to them and interact with them so that the solution reached would truly be better for all concerned. Additionally, collectiveness appears frequently in this conception because the focus of learning is not in individual change (as in the first conception), but in a change that aims to improve results in terms of the organization.

This process does not happen without its difficulties. Two barriers were noticed by the interviewees: dysfunctions in bureaucracy - a "chain" that may thwart the change process; and the excessive instability that may ensue from the state of ignorance imposed by job rotation. Interviewee \#7 tells of this concern:

Another thing that gets in the way is that, for us to be able to make these changes in a structured way, we need to update the regulations; and to do that is a long drawn-out process. (I7)

The second barrier was mentioned in the case of an organization where several individuals underwent job rotation at the same time, which led bosses and subordinates to be, at the same time, experiencing the state of ignorance that results from boundary crossing. Since learning happens with the help of "the other," having "the other" in the same stage of ignorance may result in paralyzing insecurity.

Although only two barriers characterizing this category were presented here, it is important to emphasize that the hindrance factors of the two other barriers also interfere in learning within this category. This phenomenon occurs because there is a hierarchical relationship between the three categories, wherein the third encompasses the previous two. This aspect will be presented in the next section.

To complete the characterization of this descriptive category, we must describe the meaning of learning as perceived by the interviewees. Since the learning process is understood as conducive to innovation, presumably it represents new outcomes, better performance and a higher level of client satisfaction.

\section{What we have to say about it - discussion and propositions}

The purpose of this article has been to understand how the learning experience in the job rotation situation occurs, and shed light on possible factors that may contribute to the development of an environment conducive to learning in organizations. Three categories were outlined describing the phenomenon studied (the experience of social learning in the context of organizational routines in an intensive learning situation) that illustrate the interviewees' learning conceptions.

The three conceptions illustrate learning conceptions presented previously by other theoreticians, such as Elkjaer (2004), Brandi \& Elkjaer (2011) and Cook and Brown (1999), drawing on studies on individual learning, social learning and pragmatic learning. However, the present study seeks to advance the theory, since it relates the conceptions of learning with the impacts that each of them can engender in organizational practices.

While Table 1 shows only the relationship between the descriptive categories and the explanatory dimensions, without showing the hierarchical relationship among the three categories, Figure 1, graphically, represents this relationship, which should be understood as the innovation conception (the most complex), which contains the collective-practice change conception, which, in turn, contains the individual change conception (the least complex). 
Figure 1 . Outcome Space - Conceptions Architecture.

\begin{tabular}{l} 
Learning that results in innovation \\
Learning that results in collective practice (routine) change \\
\hline Learning that results in individual change \\
\hline
\end{tabular}

Developed by the authors.

This hierarchy does not mean that the first conception is less important within organizational learning. All three conceptions have their role and cannot be understood as hermetic categories. Between conceptions 1 and 2 and between conceptions 2 and 3 , there are scenarios combining, in different ways, variations of the explanatory dimensions. For instance, there is an intermediate state between conceptions 1 and 2 whereby an individual may learn concepts through experience in routine practice. Or there may be a situation where, to solve a complex problem or address a client demand, a shift in an organizational routine must be carried out - which would represent an intermediate stage between conceptions 2 and 3 .

This notion is the basis for the first proposition: Organizations and the people who are part of it must aim to move upwards between the three conceptions if they wish to optimize their ability to innovate. Adaptive learning is necessary, since nobody wants to "reinvent the wheel" at each state, but progressing towards generative learning - i.e., which happens within organizational routines, looking inwardly and outwardly - is what fosters organizational development.

Such a movement may be achieved by means of several actions, and job rotation is the one described here. The boundary crossing, besides working as the driver for the learning of the individual crossing, may also help the individual's colleagues to expand their focal conscience, switching between different conceptions. This phenomenon happens because, after crossing the boundary, the individual starts to act as a broker (Wenger, 2000). This notion takes us to the second proposition: job rotation may favor the innovation process if, after crossing the organization's internal boundary, the individual intentionally acts as a broker, leading a new outlook on the practice and organizational routines, and contributing to a new perspective for identifying and understanding the problems related to the new context. This way, it becomes possible to eliminate bad habits, remove blind spots, and loosen rigid mental models, eventually creating a more favorable environment for generative learning and innovation.

Regarding organizational routines, brokers, if in a managerial position, may represent an exogenous agent of change. If they find themselves in an operational position, they may become endogenous factors of change as they participate in the new practices. From this notion, the third proposition consolidates: In the process of job rotation, the individual who changes position may act as an exogenous or endogenous agent of change. As an exogenous agent, they may trigger change in the ostensive aspect of the routine. As an endogenous agent, change will manifest in its performative aspect.

To conclude this discussion, the analysis of the accounts of learning experiences in job rotation scenario provided evidence that the initial assumption - job rotation is an intensive learning situation because it precipitates a conscious state of ignorance that imposes the need to learn - can be converted into a proposition. Thus, the fourth and last proposition: The conscious state of ignorance caused by job rotation drives at least one of the three types of learning: Learning that results in individual change; learning that results in collective practice (routine) change; or learning that results in innovation.

In addition, the four propositions presented here, if implemented jointly, may contribute to the development of an organization's potential to learn.

\section{And then... - final remarks}

The purpose of this article was to understand how the learning experience in a job rotation situation occurs its contents, methods, drivers and obstacles - to bring to light possible factors that may contribute to the development of an organization's ability to learn. The findings have contributed to a better understanding of how boundary crossing can lead to different learning experiences, fostering different levels of impact on the workplace context. The state of ignorance that job rotation generates can be perceived as important trigger for new learning processes and for the development of the learning capacity.

The learning experiences analyzed by the 
phenomenographic method outlined three descriptive categories: learning that results in individual change, learning that results in collective practices (routines) change and learning that results in innovation. These categories are not hermetic in themselves, and individuals may move through different conceptions without necessarily be wholly included in a single category. However, the three conceptions present distinct complexity levels, the first being the least complex, and the third, the most complex. Individuals must aim to transit throughout the three, in an upward manner.Throughout the analysis, evidence emerged that the means via which individuals must travel from the first to the third learning conception involves relationships with varying forms of experience, along the lines of Dewey (1916[1981]), i.e., what type of trying generates an undergoing to a different level. Investigating this possible relationship may be a subject for future research, for such an analysis was outside the scope of this paper. A possible research question could be, "How to foster types of experience that are more qualified, that generate undergoings that are more innovative?"

The properties of each category were identified by the variation found in five dimensions: 1) the concept of learning, 2) what drives learning, 3) what one learns, 4) how one learns, 5) what hinders learning and 6) what learning represents. From these findings, we presented some propositions that may contribute to the development of organizations' learning capacity.

We consider unlocking the learning process black box in a job rotation scenario an important contribution of this research. The outcome space represents substantial theoretical framework, presenting the properties of learning conceptions in a detailed manner, and, due to being built by induction, we understand that this paper contributes to reducing the gap between the formal knowledge produced by academics and the applied knowledge that practitioners need, enabling an advancement in management practices.Also concerning managerial contributions, this investigation reveals new ways to enhance the impact of learning in organizations. Diagnosing, for example, the learning conception of individuals within their organizations may be a valuable practice for managers, who will, after this diagnostic, be able to outline strategies to facilitate the movement from the least complex conception to the most complex. The proposal of actions that lead individuals to cross boundaries within organizations, imposing a conscious state of ignorance, may be considered an important premise in the organizational learning plans of companies that wish to optimize their innovation processes.

\section{References}

Åkerlind, G. (2005). Learning about phenomenography: Interviewing, data analysis and the qualitative research paradigm. In Bowden, J. A. and Green, P. (Orgs.), Doing developmental phenomenography (pp. 32-46). Melbourne: Qualitative Research Methods Series, RMIT University Press.

Åkerlind, G. (2005b). Variation and commonality in phenomenographic research methods. Higher Education Research \& Development, 24(4), 321-334.

Argyris, C. (1991). Teaching smart people how to learn. Harvard Business Review, 4(2), 4-15.

Bowden, J.A. (2005). Reflections on the phenomenographic team research process (1133). In Bowden, J.A. and Green, P. (Orgs.), Doing developmental phenomenography, Qualitative Research Methods Series, Melbourne: RMIT University Press.

Campion, M., Cheraskin, L. \& Stevens, M. (1994). Career-Related Antecedents and Outcomes of Job Rotation. Academy of Management Journal, 37(6), 15181542.

Cook, S.D.N. \& Brown, J. S. (1999). Bridging Epistemologies: The Generative Dance Between Organizational Knowledge and Organizational Knowing. Organization Science, 10(4), 381-400.

Delors, J. (Coord.) (1996). Educação: um tesouro a descobrir. Relatório para a UNESCO da Comissão Internacional de Educação para o Século XXI, Brasília: UNESCO.

Dewey, J. (1916 [1981]). Democracy and education: An introduction to the philosophy of education. In McDermott, J. J. (ed.), The Philosophy of John Dewey. Chicago: The University of Chicago Press.

Easterby-Smith, M. \& Lyles, M. (2011). The evolving field of Organizational learning and Knowledge Management. In Easterby-Smith, M. and Lyles, M., The Blackwell Handbook of Organizational Learning and Knowledge Management (01-20). Chichester: Blackwell Publishing. 
Elkjaer, B. (2004). Organizational Learning: The

'Third Way'. Management Learning, 35(4), 419-434.

Eriksson, T. \& Ortega, J. (2006). The adoption of job rotation: testing the theories. Industrial and Labor Relations Review, 59(4), 653-666.

Feldman, M. (2003). A performative perspective on stability and change in organizational routines. Industrial and Corporate Change. 12(4), 727-752.

Feldman, M. \& Orlikowski. W. (2000). Theorizing Practice and Practicing Theory. Organization Science, 11(6), 611-629.

Gherardi, S. (2011). Organizational Learning: The Sociology of Practice. In Easterby-Smith, M. and Lyles, M., The Blackwell Handbook of Organizational Learning and Knowledge Management (43-66). Chichester: Blackwell Publishing.

Goldman, E.; Scott, A. \& Follman, J. (2015).

Organizational practices to develop strategic thinking. Journal of Strategy and Management, 8(2), 155175.

Green, P. (2005). A rigorous journey into phenomenography. In Bowden, J. A. and Green, P. (Orgs.), Doing developmental phenomenography (32-46). Qualitative Research Methods Series, Melbourne: RMIT University Press.

Howard-Grenville, J. \& Rerup, C. (2017) A Process Perspective on Organizational Routines. In: Langley A.; Tsoukas, H. The SAGE Handbook of Process Organization Studies. SAGE Publications. Kindle Edition.

Lave, J. \& Wenger, E. (1991). Situated learning: legitimate peripheral participation. Cambridge: Cambridge University Press.

Marton, F. \& Booth, S. A. (1997). Learning and awareness. Mahwah: Lawrence Erlbaum Inc. Publishers.

McGill M. E.; Slocum J. W. \& Lei, Jr. D. (1992). Management Practices in Learning Organizations. Organizational Dynamics, 21(1), 05-17.

Parmigiani, A. \& Howard-Grenville, J. (2011). Routines Revisited: Exploring the Capabilities and Practice Perspectives. The Academy of Management Annals, 5(1), 413-453.
Pentland, B. \& Feldman M. (2005). Organizational Routines as unit of analysis. Industrial and Corporate Change, 14(5), 793-815.

Pettit, K.; Crossan, M. \& Vera, D. Organizational Learning and Knowledge Processes: A Critical Review. In: Langley A.; Tsoukas, H. The SAGE Handbook of Process Organization Studies. SAGE Publications. Kindle Edition.

Roberts, J. (2012). Organizational Ignorance: Towards a managerial perspective on the unknown. Management Learning, 44(3), 215-236.

Schembri, S. \& Sandberg, J. (2011). The experiential meaning of service quality. Marketing Theory, 11(2), 165-186.

Wenger, E. (1998). Communities of Practice: learning, meaning and identity. Cambridge: Cambridge University Press.

(2000). Communities of Practice and

Social Learning Systems. Organization, 7(2). 225-246.

Wenger, E.; McDermott, R. \& Snyder, W.M. (2002). Cultivating Communities of Practice, Boston: Harvard Business Press.

Wexley, K. \& Baldwin, T. (1986). Posttraining Strategies for Facilitating Positive Transfer: an Empirical Exploration. Academy of Management Journal, 29(3), 503-520.

Wilkesmann, M. \& Wilkesmann, U. (2011). Knowledge transfer as interaction between experts and novices supported by technology. VINE, 41(2), 96-112. 